\title{
Framing of Maternal and Child Healthcare Issues in Nigerian Newspapers
}

\author{
Raheemat Adeniran \\ Lagos State University - raheemat.adeniran@lasu.edu.ng \\ Olujimi Kayode \\ Lagos State University - olujimi.kayode@lasu.edu.ng \\ Lai Oso \\ Lagos State University - laioso@ymail.com
}

\begin{abstract}
The mass media are important for wide dissemination of health information. The frame of reference adopted in the reportage of health issues tends to influence people's perception towards health related issues. Studies examining framing of health issues have found the media wanting in their reportage of health. This study extends the frontier of framing analysis of health coverage in the media by examining framing of maternal and child healthcare $(\mathrm{MCH})$ issues in Nigerian newspapers. Using the content analyses method, two categories of frames - public health frame, and coping versus alarm message frame - were examined

purposively sampled over a 12 -month period resulting in the analysis of $1,235 \mathrm{MCH}$-related editorial items. The study found minimal adoption of public health frame with only $12 \%$ adoption rate, and dominant adoption of coping frame over alarm frame with rare combination of both. The findings reflect the implication of greater reliance on official sources for health stories in the media, resulting in lack of context in reported stories to aid proper understanding of issues. The study calls for better framing of health related issues in the media to generate appropriate attention to possibly drive development in the health sector.
\end{abstract} in the study. Four national newspapers were

Keywords: Maternal health, child health, framing analysis, Nigeria.

\section{Enquadramento das Questões de Saúde Materna e Infantil nos Jornais Nigerianos}

\section{Sumário}

Os meios de comunicação são importantes para a ampla divulgação de informações sobre saúde. $\mathrm{O}$ quadro de referência adoptado para reportar problemas de saúde tende a influenciar a percepção das pessoas em relação a questões relacionadas com a saúde. Estudos 
que analisaram o enquadramento noticioso das questões de saúde descobriram as lacunas dos meios de comunicação nas suas reportagens sobre saúde. Este estudo estende a fronteira da análise de enquadramento noticioso da cobertura da saúde nos meios de comunicação, examinando como são enquadradas as questões de saúde materna e infantil (SMI) em jornais nigerianos. Utilizando a metodologia de análise de conteúdo, duas categorias de enquadramentos - o quadro de saúde pública e coping versus alarme - foram estudadas no estudo. Para este propósito, foi composta uma amostra de quatro jornais num período de 12 meses, resultando na análise de 1.235 itens editoriais relacionados com SMI. O estudo aferiu uma adopção mínima do enquadramento de saúde pública, com uma taxa de apenas $12 \%$, e a adopção dominante do quadro de cobertura sobre o enquadramento noticioso de alarme, sendo rara a combinação das duas categorias. As resultados refletem a implicação de uma maior confiança nas fontes oficiais sobre artigos de saúde nos meios de comunicação, resultando numa falta de contexto nas histórias relatadas que ajudem a um entendimento adequado dos problemas. O estudo sustenta um melhor enquadramento dos problemas relacionados com a saúde nos meios de comunicação social, para permitir uma atenção adequada que possa impulsionar o desenvolvimento do sector da saúde.

Palavras-chave: Saúde materna, saúde infantil, análise de enquadramentos noticiosos, Nigéria.

\section{INTRODUCTION}

The mass media are often relied upon as effective tool for creating awareness about health information and for mass mobilisation. They provide the platform for health information to be disseminated to diverse audience with very wide reach (Atkin \& Arkin, 1990). Information about health, illness and medicine can be shared in the mass media through news, entertainment and advertisements (Kline, 2003). Thorson observes that scholars have established inherent potential of health news to "wield influence at both the individual and group levels" (2006, p. 176). She submits that health information provided in the news media can influence individuals by promoting "changes in health-related knowledge, attitudes and/or behaviours", in addition to raising "awareness of health issues among the public and policymakers" (Thorson, 2006, pp. 176-177). Studies have found that members of the public are increasingly relying on the mass media for their health information needs (Atkin \& Arkin, 1990; Levey, 2013). Kline notes that the general public often rely on the mass media to simplify scientific data and findings, and also to report on activities of "gov- 
ernments, legal, corporate and non-profit entities that will most likely impinge on (their) health-related decision-making" (2003, p. 560). Wang and Gantz (2010) notes the availability of health information in the media can influence public reaction and understanding of health-related issues. Media representations of health influence our understanding and perceptions of health issues and contribute to the promotion of public health (Ahmed \& Bates, 2013).

However, the mass media are not just to provide basic health information for the audience. Scholars have argued for the use of media for public health advocacy (Wallack \& Dorfman, 1996) especially in developing countries like Nigeria. The media in such societies are expected to play the advocacy role by generating issues and setting agenda for discussion around public health issues, with the aim of influencing policy decisions to promote desired policy change. Wallack and Dorfman describe media advocacy as the use of the mass media "to promote public health goals by strategically applying pressure for policy change" (1996, p. 293). They observe the potential of media advocacy to foster public discussion of health issues likely to be ignored by policy and decision-makers by "broadening participation and increasing the diversity of community voices" (1996, p. 294). The emphasis of media advocacy is not just to get media mention, but to present issues in the most effective way to achieve desired result. Aside advocacy, mass media are also considered formidable tools in communication campaigns and their impact has been examined by communication scholars. A well-executed health mass media campaigns could have small-to-moderate effects not only on health knowledge, beliefs, and attitudes, but on behaviours as well (Kayode \& Thanny, 2013; Kline, 2006).

To achieve any meaningful impact, such messages need to be strategically created and positioned in the mass media. The message presented must be accurate and of high quality, reflecting a range of topics which must be treated regularly and in-depth, and should be compellingly written (Thorson, 2006). However, Thorson (2006) notes that such quality of coverage required for communicating health messages is increasingly being threatened by the commercialisation drive of many media organisations. This is true of contemporary media industry in Nigeria, with pressing economic challenges resulting in fierce struggle for survival of individual media organisations. In the newspaper industry where rate of attrition is rather high (Dare, 2009; Olukotun, 2017), the consideration for survival in the industry is likely to reign high and above the publication of health stories which is hardly considered a priority sector by editors (Adeniran, 2018; Bello, 2015). 
Despite these challenges, the media in Nigeria are still expected to promote development of the country's health sector by building and setting agenda on health issues for appropriate actions from varied stakeholders. Specifically, the Nigerian Health Promotion Policy mandates the media to:

Provide information of healthy lifestyles and practices; create enabling environment for the adoption of healthy behaviours; advocate for the enactment of legislation to support health promotion activities; set an agenda for health promotion nationwide; (and) collaborate with health promotion/education divisions of Federal and State Ministries of Health in the dissemination of health promotion messages. (Federal Ministry of Health, Nigeria, 2006, p. 34)

The need for media involvement in promotion of healthcare is pertinent considering the poor state of the Nigerian health sector, with the country ranking below global and African regional average across various health indices (World Health Organisation, 2014).

Maternal and child healthcare $(\mathrm{MCH})$ is an important developmental issue affecting every constituency in Nigeria, though with wide disparities across the geographical regions and social strata (National Population Commission \& IFC International, 2014). It requires continuing enlightenment of the general public and commitment of policymakers to ensure the provision of adequate $\mathrm{MCH}$ for all. The mass media are a veritable tool that can be explored to achieve mass enlightenment, and provide basic life-saving information to effect behavioural change which could lead to improved $\mathrm{MCH}$. There is an increasing demand and need for accurate, relevant, rapid and impartial public health information by people, and a growing reliance on mass media as the main source of information (Levey, 2013). Unfortunately, health issues hardly make front page headlines of newspapers or highlights of broadcast newscasts. Studies (e.g. Jimoh, 2011; Kayode \& Adeniran, 2012; Soola \& Alawode, 2013) have shown that health issues are under-reported in Nigerian media. The limited level of coverage may however be enhanced through appropriate framing of related issues in the media, with adopted frame of reference influencing public understanding of such issues. Previous studies on coverage of health related issues in Nigerian media often focused on extent of coverage with emphasis on frequency and type of coverage; establishing the under-reportage of health issues in Nigerian media. Beyond coverage however, the framing of health issues could go a long way in swaying public opinion, 
and influencing agenda for public discourse, possibly attracting attention of policy makers to stimulate desired change in the health sector.

This study thus examines framing of $\mathrm{MCH}$ issues in Nigerian newspapers through the extent of adoption of two categories of frames used in previous studies. First is the public health frame (Gruhn \& Hawkins, 2004; Hawkins \& Linvill, 2010) which describes the combined inclusion of contextual information, risk factors, and preventive measures in a single story. The other category of frame examined is the message frames, encompassing coping, alarm, and mixed message frames (Chang, 2012). Coping frame describes stories that focus on successful measures in place to resolve an issue in its reportage, while the alarm frame emphasises its severity. The mixed frame combines both components of coping and alarm message frames. Examining these categories of frames thus enables an assessment of media coverage of these issues beyond frequency or extent of coverage.

\section{THEORETICAL FRAMEWORK: EMPHASIS FRAMING}

This study is premised on the sociological orientations of media framing, termed "emphasis framing" (Cacciatore, Scheufele, \& Iyengar, 2016). Two varying aspects of framing have been of interest to media scholars over the years. In the first instance, framing is examined in relations to the workings of journalists in their presentation of media information to the public. The second considers framing as an effect paradigm relating more to the effect media information evokes in the audience, largely influenced by a number of factors one of which is the manner the information is presented. McQuail offers a succinct classification of the dual meanings of framing thus:

One refers to the way in which news content is typically shaped and contextualised by journalists within some familiar frame of reference and according to some latent structure of meaning. A second, related meaning concerns the effect of framing on the public. The audience is thought to adopt the frames of reference offered by journalists and to see the world in a similar way. $(2005$, p. 555)

Scholars have provided varied definitions of the emphasis-based definition of framing over the years. Tankard, Hendrickson, Silberman, Bliss, and Ghanem (1991, p. 3) 
describe media frame as "a central organising idea for news content that supplies a context and suggests what the issue is through the use of selection, emphasis, exclusion and elaboration" (cited in Tankard, 2001, pp. 100-101). Among the most popular definitions is Entman observation that "framing essentially involves selection and salience" and that "to frame is to select some aspects of a perceived reality and make them more salient in a communicating text; to promote a particular problem definition, causal interpretation, moral evaluation, and/or treatment recommendation for the item described" (1993, p. 52). Entman explains salience as "making a piece of information more noticeable, meaningful, or memorable to audiences" (1993, p. 53). Entman further considers it a process of "selecting and highlighting some facets of events or issues and making connections among them so as to promote a particular interpretation, evaluation, and/ or solution" (2004, p. 5). D'Angelo hints that critical scholars have argued "that frames are the outcome of newsgathering routines by which journalists convey information about issues and events from the perspective of values held by political and economic elites (which tend to) dominate news coverage" (2002, p. 876).

This notion of framing has however been a subject of criticism in recent years. Cacciatore and colleagues descry the idea of considering the "selection of one set of facts or arguments over another" as a frame suggesting that it tends to promote studies "manipulating what an audience receives rather than how equivalent information is presented" (2016, p. 10). The authors note that "emphasis framing" operates by making "some aspects of a problem or communication more accessible, visible, or salient to an audience" thus positioning framing as "a product of accessibility as opposed to applicability” (2016, p. 11). They view Entman's (1993) salience-based definition too vague to have practical value, especially its perception inclination "that any number of differences in communication constitutes a difference in framing" (2016, p. 13).

Despite the criticism however, the emphasis-based definitions of framing is appropriate to this study. The sociological tradition is credited for expanding the scope of applicability of framing in media research. This study is limited to the adoption of specific frames in newspaper coverage of $\mathrm{MCH}$ issues, with their suggestive interpretation. It excludes audience interpretations of adopted frames. This study thus examines the extent of adoption of two categories of frames, public health frame (Hawkins \& Linvil, 2010), and message frames incorporating coping versus alarm frames (Chang 2012), in newspaper coverage of $\mathrm{MCH}$ issues in Nigeria. A number of studies examining coverage of health issues in the media had explored emphasis- 
based framing to evaluate media performance in communicating health issues. Some of such studies are discussed next to provide context to understanding media coverage and framing of health issues.

\section{MEDIA COVERAGE OF HEALTH}

Studies have shown that health information in the media is "often compromised by inaccuracies, misrepresentations, and omissions, as well as inappropriate role modelling" (Kline, 2003, p. 561; see also Gottfredsdottir, Magnúsdóttir, \& Hálfdánsdóttir, 2015; Lebow, 1999). The factual inaccuracies in health information manifests in the manner health messages are framed in the media. This calls for concern as such framing could make health information potentially misleading. The media have also been found with the tendency of attributing individual responsibility for health in their coverage of health issues, while disregarding the socio-political factors that limit the capacity of the individual to be fully responsible for their health status (Dorfman, Thorson, \& Stevens, 2001, cited in Thorson, 2006; Dorfman, Wallack \& Woodruff, 2005). In addition, studies have found that health issues in the media are hardly reported in-depth, but given shallow coverage across various conventional media platforms (e.g. Laboli, Caselli, Filice, Russi \& Belletti, 2010; Soola \& Alawode, 2013; Wang \& Gantz, 2010).

For example, Soola and Alawode (2013) examined coverage of health and related issues in selected broadcast media in Lagos, Nigeria. Their study combined content analysis of major news bulletins of government and private owned broadcast stations in Lagos, with survey research method using face-to-face interviews with reporters from selected broadcast stations in the state. They found low reportage of health and related issues with health stories appearing in less than five percent of the sampled news bulletins. Health was not an established beat in the newsroom of all the sampled broadcast stations as health was treated as a general beat. Health issues were reported mainly "when there is a happening, or event; or a prominent personality is involved" (2013, p. 218). Soola and Alawode (2013) thus related their findings to the 'vulture reporting hypothesis' formulated by Nwosu in 1996 (Nwabueze, 2005/2006). Citing Nwosu (1996), Nwabueze explains the vulture reporting hypothesis as describing media practice of feasting on an issue while it is on the front burner of public discussion, and abandoning it thereafter. Soola and Alawode (2013) thus decry the non- 
prioritisation of health news in broadcast media, noting it as a reflection of the larger Nigerian societal attitude towards health with great consequences for the nation.

Studies examining coverage of health issues in the media have explored framing from various perspectives, providing understanding of how frames are evaluated in media coverage of health issues. A number of studies analysing media coverage of specific health issues often examine adoption of specific frames. Gruhn and Hawkins (2004) examined the adoption of public health frame and non-public health frame in United States (US) newspapers coverage of children's health issues using content analysis method. In their examination of adoption of public health frame, Gruhn and Hawkins identified three basic components, "information connecting the health issue to the larger social and environmental context, expose risk factors related to the health issue and prevention information" (2004, p. 15) all of which must be included in a story to be accepted as public health framing. Their study found that less than 10 percent $(9.4 \%)$ of the analysed stories adopted the public health frame with the remaining having non-public health frame. Gruhn and Hawkins note that "the extremely limited use of the public health frame indicates a lack of depth in the reporting of those topics, leaving readers ill-equipped to address health issues affecting children" (2004, p. 19).

Hawkins and Linvill (2010) also examined the extent of adoption of public health frame in their content analysis of childhood obesity in US newspapers using Gruhn and Hawkins (2004) criteria. The prevention information noted in their analysis was however "expanded to incorporate references to measures recommended to not only prevent occurrences of a problem (preventatives), but also to remedy the situation (correctives)" (Gruhn \& Hawkins, 2004, p. 712). The authors found a larger rate of public health frame adoption with 48 percent of their sampled 210 articles adopting the public health frame. Among the three components of public health frame, information regarding prevention of, or correctives to childhood obesity was the least occurring component appearing in about 52 percent $(n=104)$ of sampled articles. Risk factors of childhood obesity were recorded in 84 percent, while the issue was mostly related to the larger societal context with 97 percent rate of inclusion in the sampled stories.

The researchers note that the adoption of public health frame in the coverage of childhood obesity provides the expected frames of reference on the issue as suggested by Entman, in terms of "defining problems, diagnosing causes, making moral judgments regarding the causal agents and their effects, and suggesting remedies" (Ent- 
man, 1993, p. 714). They also note that the high rate of individual attribution of preventatives and correctives for childhood obesity tend to ignore societal changes and policy intervention necessary to wholly address the issue.

Chang (2012) examined news coverage of health-related issues in Taiwanese newspapers and categorise the adopted frames of coverage as alarm, coping and mixed, based on specific contents published in the stories. The researcher analysed headlines and contents of 388 health-related news stories published in selected samples from four leading Taiwanese newspapers between April 15 and June 16, 2009. Chang used alarm frames to describe health stories focusing on "perceived severity of an issue, people's perceived vulnerability to its threats, and the need for enhanced alertness" (2012, p. 112). Coping frames described health stories focusing on tips for prevention, detection, treatment and solution to the health issues being reported. The mixed frames captured health stories combining both coping and alarm frames in one story. Chang notes the likelihood of alarm frame being prevalent in published health stories which was confirmed in her study. The researcher notes the possibility of threats to health issues being favoured in the media due to perceived newsworthiness of such stories. The findings from the content analysis were later subjected to experimental and survey studies to examine possible effect of dominating health news with alarm frames. Chang decries the dominance of alarm frame in health news, stressing the importance of adopting mixed frame, combining threats relating to a health issue with information to help people respond to such threats, for effective public health promotion.

In furtherance of these studies, the present study uses emphasis-based definitions of framing in examining newspaper coverage of $\mathrm{MCH}$ issues in Nigeria. It examines two aspects of framing adopted in earlier studies, level of adoption of public health framing, and message framing incorporating coping, alarm and mixed frames of $\mathrm{MCH}$ issues in Nigerian newspapers. In a developing country like Nigeria, where newspaper is considered an elitist medium, this study examines the maximisation of the potential of the medium in appealing more to policymakers and opinion leaders in their coverage of $\mathrm{MCH}$-related issues to drive the desired change for improved $\mathrm{MCH}$ in the country. Using the "list of frames" approach to framing analysis, this study examines the extent of adoption of public health frame in newspapers coverage of $\mathrm{MCH}$ issues, noting the inclusion rate of each public health framing element. It also examines the alarm and coping message frames by comparing their levels of adoption and combination (mixed frames) in Nigerian newspapers. The following research questions thus guided the study: 
RQ 1: What is the level of adoption of public health frame in newspaper coverage of maternal and child healthcare issues?

RQ 2: What is the extent of adoption and combination of coping and alarm frames in Nigerian newspapers coverage of maternal and child healthcare issues?

\section{METHOD}

The "list of frames" approach to framing analysis was adopted for this study. The approach, conceptualised by Tankard, Hendrickson, Silberman, Bliss and Ghanem (1991, cited in Tankard, 2001) examines frames in terms of "inclusion and exclusion of certain key terms". It is aimed at reducing subjectivity in the development and identification of frames in media contents. Tankard (2001) identified the following as steps to using the "list of frames" in media frame analysis: (1) Make the range of possible frames explicit; (2) Put the various possible frames in a manifest list (3) Develop keywords, catchphrases and symbols to help detect each frame (4) Use the frames in the list as categories in a content analysis; and (5) Get coders to code articles or other contents into these categories.

Based on these guidelines, the study conducts a framing analysis of Nigerian newspapers coverage of MCH issues over a 12-month period from July 2015 to June 2016. The period of study was sampled to examine the coverage of $\mathrm{MCH}$ issues around the end of the Millennium Development Goals (MDG) set deadline and the beginning of the later Sustainable Development Goals (SDG) when it was obvious Nigeria will be unable to meet the MCH-related set goals of the MDG. Four nationally circulated newspapers, The Punch, The Nation, Leadership and Daily Trust, were purposively sampled for their popularity, nationally and in specific regions of the country. There is currently no independent Audit Bureau of Circulation in the country and newspapers jealously guard their circulation figures. Hence, no official data exists on circulation figures of newspapers in Nigeria. However, these four sampled newspapers are often noted among leading circulating newspapers (e.g. Olukotun, 2017). Two of the newspapers, Leadership and Daily Trust, both published in Abuja, the nation's capital, and widely circulated within the northern region and with inclination towards projecting northern interests, were sampled to represent newspapers published in the northern region of the country. The Punch and The Nation both published in Lagos, the commercial nerve centre and media capital of the country, represent the southern region which historical- 
ly, has dominated the Nigerian media space. Sampling based on these distinct regions of the country enables us to examine if location and ethnic inclination of these newspapers which sometimes influence media coverage of issues in Nigeria (Oso, 2012) also sway coverage of $\mathrm{MCH}$ issues especially since the issues are more severe in the northern parts of the country. For example, maternal mortality rates which is highest in the Northeast region of the country at 1,549/100,000 live births is almost 10 times higher than the rate in the Southwest at 165/100,000 live births (Nigeria Health Watch, 2017).

Having explicitly defined the constituents of adopted frames to be examined in this study as discussed in previous studies (Chang, 2012; Gruhn \& Hawkins, 2004; Hawkins \& Linvill, 2010), a coding guide, with seven content categories, was developed to elicit data for the study. The variables and respective categories measured included newspaper, content type, publication column/section, public health frame component included, level of adoption of public health frame, message frame, and story source. All editorial contents spanning news stories, features, editorials, letters, audience feedback, etc. published on any issue relating to $\mathrm{MCH}$ during the sample period formed the units of analyses for the study.

The coding guide was pre-tested through a pilot study and subsequently subjected to inter-coder reliability using Krippendorff's alpha (KALPHA). The total number of newspaper items to be analysed were unknown at the commencement of the coding process as the researchers had to flip through every edition of the newspapers for identification and coding of published $\mathrm{MCH}$-related items. Hence, the pilot and inter-coder reliability testing were limited to a month edition of each of the sampled newspapers. January 2016 was randomly selected for these exercises. One of the researchers (RA) flipped through the editions and identified $108 \mathrm{MCH}$-related editorial items which were used to pre-test the instrument. Required adjustments were made to remove perceived ambiguities in consultation with the research collaborators. The adjusted coding guide was then used by one of the researchers (RA) and another coder for the inter-coder reliability exercise using the pre-identified $108 \mathrm{MCH}$-related editorial items from the pilot testing. The final agreement between the two coders for each of the examined variable resulted in varied KALPHA value ranging from .915 to 1.00 . The resultant KALPHA values for each of the variables examined were satisfactory to the researchers on the basis of perceived ease or otherwise in coding each variable. All physical editions of the sampled newspapers over the sample period were subsequently examined for published $\mathrm{MCH}$-related items resulting in analysis of 1,235 items published on varied MCH-related issues. 


\section{RESULTS}

\section{Preliminaries}

The study analysed 1,235 published editorial contents spanning news stories, features, editorials, letters, audience feedback, etc. The bulk of the analysed items were mostly news (60\%) and features (24\%); and often published (98\%) in the news, features and health sections of the sampled newspapers. The newspapers published from the northern region of the country, Daily Trust and leadership, had the highest percentage share of the analysed stories as presented in Figure 1 below.

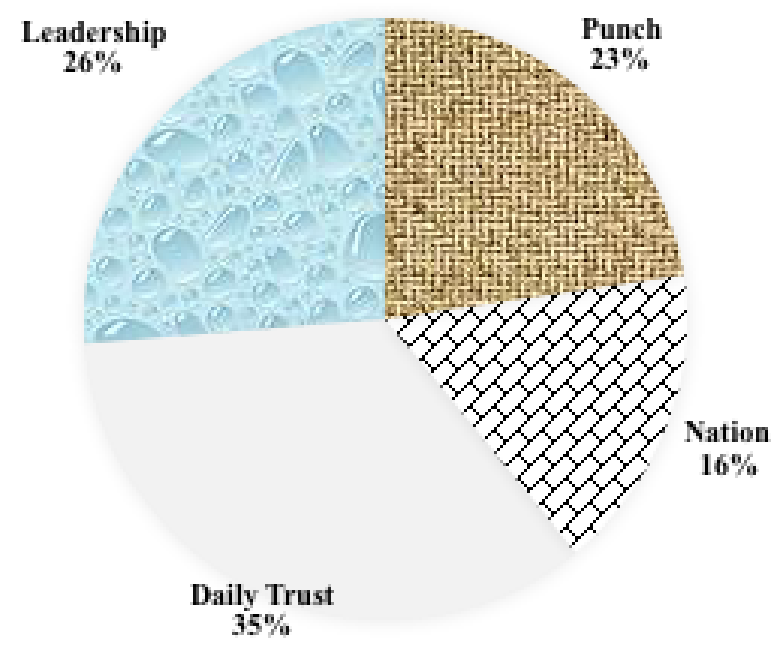

Figure 1. Percentage distribution of analysed MCH-related items. Source: Field data, 2017

\section{Public health Framing}

In examining public health framing of $\mathrm{MCH}$ issues for the framing analysis, the level of adoption of public health frame was graded on a scale of zero to three. As noted by Gruhn and Hawkins (2004; see also Hawkins \& Linvill, 2010), media contents can only be categorised as adopting the public health perspective when they incorporate all three elements of public health frame comprising: (1) providing information connecting the health issue to the larger social and environmental context, (2) exposes risk factors related to the health issue, and (3) includes prevention information which encompasses efforts at addressing the health issue. 
Table 1

Adoption of public health frame in analysed $\mathrm{MCH}$-related items

\begin{tabular}{|c|c|c|c|c|c|}
\hline \multirow{2}{*}{$\begin{array}{l}\text { Level of Adoption } \\
\text { Public Health } \\
\text { Frame }\end{array}$} & \multicolumn{4}{|c|}{ Newspapers (Percentage) } & \multirow{2}{*}{ TOTAL } \\
\hline & Punch & Nation & D. Trust & Leadership & \\
\hline Level 0 & 4.6 & 7.9 & 4.4 & 3.7 & 4.9 \\
\hline Level 1 & 32.2 & 34.0 & 38.2 & 41.8 & 37.1 \\
\hline Level 2 & 50.7 & 40.4 & 45.7 & 45.2 & 45.8 \\
\hline Level 3 & 12.5 & 17.7 & 11.7 & 9.3 & 12.2 \\
\hline Total & 280 & 203 & 427 & 325 & 1235 \\
\hline (n) & $100 \%$ & $100 \%$ & $100 \%$ & $100 \%$ & $100 \%$ \\
\hline
\end{tabular}

Source: Field data, 2017

The level of adoption of public health frame was therefore coded based on the number of the public health frame elements included in each analysed item. Hence, the public health frame adoption of items lacking any of the components were rated as 'Level 0', while those incorporating all three components were rated 'Level 3'. However, based on the pre-condition for categorisation of public health framing, only contents integrating all three elements, rated and coded as 'Level 3' are considered to have adopted the public health frame. Hence, based on data presented in Table 1 , only about one in eight $(12.2 \%, \mathrm{n}=151)$ of the $1,235 \mathrm{MCH}$-related items analysed in the study adopted the public health frame; covering the issues from the public health perspective. The largest percentage of coverage, nearly half $(45.8 \%, n=566)$, were rated 'Level 2' representing items including any two of the public health frame components. About 37 percent $(37.1 \%, \mathrm{n}=458)$ of the analysed items included at least one of the identified public health components, while one in twenty $(4.9 \%, n=60)$ had none. Thus, the analysed items $(n=1,235)$ mostly adopt at least one component of public health framing $(95.1 \%, n=1,175)$, even though only one in eight $(12.2 \%$, $\mathrm{n}=151$ ) were actually framed using the public health perspective.

The same trend was maintained across the four sampled newspapers. The Nation, which published the least number of stories, however, had the highest percentage adoption of public health framing $(17.7 \%, \mathrm{n}=36)$ of its published 203 contents, compared to the other three newspapers with about nine to 13 percent. 
The study further examined the specific components of public health frame included in the MCH-related items analysed in the study. The data exclude the 60 published contents with none of the public health frame components. The classifications of the public health frames components (Gruhn \& Hawkins, 2004; Hawkins \& Linvill, 2010) adopted in the study as presented in Table 2 are as follow:

Point 1: Provides information connecting the health issue to the larger social and environmental context

Point 2: Exposes risk factors related to the health issue

Point 3: Includes prevention information, as well as efforts being put in place to address the issues.

Table 2

Composition of public health frame elements in analysed items

\begin{tabular}{|c|c|c|c|c|c|}
\hline \multirow{2}{*}{$\begin{array}{l}\text { Adopted Public } \\
\text { Health Frame }\end{array}$} & \multicolumn{4}{|c|}{ Newspapers (Percentage) } & \multirow{2}{*}{ TOTAL } \\
\hline & Punch & Nation & Daily Trust & Leadership & \\
\hline Points $2 \& 3$ & 52.8 & 43.3 & 44.9 & 45.0 & 46.5 \\
\hline Point 3 only & 28.5 & 34.8 & 32.4 & 30.7 & 31.4 \\
\hline Points $1,2,3$ & 13.1 & 19.3 & 12.2 & 9.6 & 12.9 \\
\hline Point 2 only & 5.2 & 2.1 & 7.6 & 12.7 & 7.5 \\
\hline Points $1 \& 3$ & 0.4 & 0.0 & 2.2 & 1.0 & 1.1 \\
\hline Points $1 \& 2$ & 0.0 & 0.5 & 0.7 & 1.0 & 0.6 \\
\hline Point 1 only & 0 & 0 & 0 & 0 & 0 \\
\hline Total & $100 \%$ & $100 \%$ & $100 \%$ & $100 \%$ & $100 \%$ \\
\hline (n) & $(267)$ & $(187)$ & $(408)$ & (313) & $(1175)$ \\
\hline
\end{tabular}

Source: Field data, 2017

The highest combination of public health frame components, adopted in the coverage of $\mathrm{MCH}$-related issues, combined Points 2 and 3 which covered items providing risk factors, and preventive information which also included efforts being put in place to address the issues (Hawkins \& Linvill, 2010). Almost half of the 1,175 newspaper items $(46.5 \%, \mathrm{n}=546)$ with at least one of the public health frame components included Points 2 and 3 only. This was followed by components containing only preventive information (Point 3) which accounted for about one in three $(31.4 \%$, 
$\mathrm{n}=31.4$ ). Contents fully adopting the public health frame is third in this category accounting for roughly one in eight $(12.9 \%, \mathrm{n}=151)$ of contents with at least one of the public health frame components. None of the items included Point 1 only; simply reporting issues within its social and environmental context. This may be understandable as it seems least likely to report an issue in context without discussing its risk factors, or providing preventive information. The least included components were combination of contextual reporting of an issue, with its risk factors (Points 1 and 2 ) with less than one percent occurrence $(0.6 \%, n=7)$. Combination of contextual reporting and preventive information (Points 1 and 3 ) were equally low with just 1.1 percent ( $\mathrm{n}=13$ ) occurrence. Items including just risk factors (Point 2 only) accounted for about 8 percent $(7.5 \%, \mathrm{n}=89)$.

All four sampled newspapers recorded similar trend in their most recorded combinations of the public health frame components. Slight variations, however, exists among the least recorded combinations. Punch and Daily Trust had similar trend with combinations of Points 1 and 2, Points 1 and 3, and Point 2 only being the least combinations in that order. Leadership combined Points 1 and 2, and Points 1 and 3, as its least occurring combinations with only one percent occurrence among its published contents. The Nation recorded no content having Points 1 and 3, and its least included combinations were Points 1 and 2, and Points 2 only.

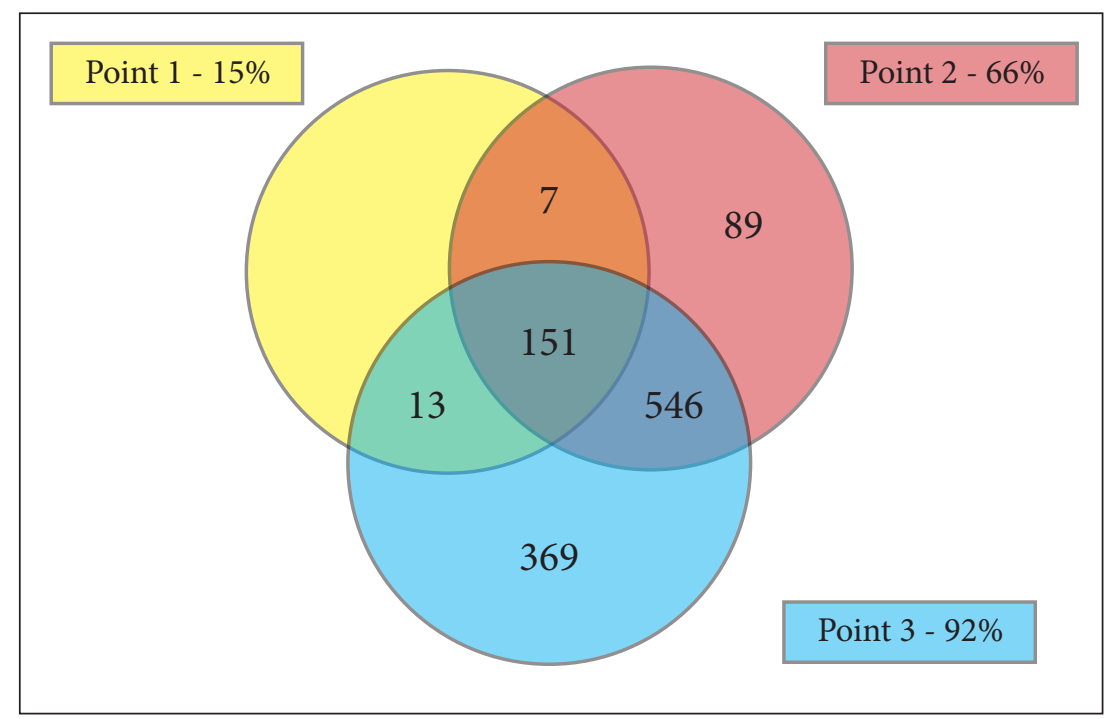

Figure 2. Inclusion rate of public heath framing components in analysed contents. Source: Field data, 2017 
A further analysis of the inclusion of each of the public health components (Figure 2) shows that Point 3, preventive information and efforts being put in place to address the issues (Hawkins \& Linvill, 2010) had the highest inclusion rate of almost 92 percent $(91.8 \%, \mathrm{n}=1,079)$ of the 1,175 items with at least one public health frame component. Items exposing risk factors of reported $\mathrm{MCH}$ issues recorded 66 percent (65.6\%, $n=793$ ) inclusion, appearing in two out of three of the analysed items. Those providing necessary information to place reported issues in perspective, by connecting specific issue of focus to the larger social and environmental context for proper understanding, however, had the least inclusion rate featuring only in less than 15 percent $(14.6 \%, n=171)$ of analysed items with at least one public health frame component.

\section{Message framing: Coping, Alarm and Mixed frames}

Table 3

Message frames adopted in analysed MCH-related items

\begin{tabular}{lccccc}
\hline \multirow{2}{*}{ Message Frame } & \multicolumn{4}{c}{ Newspapers (Percentage) } & \multirow{2}{*}{ TOTAL } \\
\cline { 2 - 5 } & Punch & Nation & Daily Trust & Leadership & \\
\hline Coping & 66.1 & 74.4 & 61.8 & 65.5 & 65.8 \\
Alarm & 32.8 & 25.1 & 36.3 & 32.7 & 32.7 \\
Mixed & 1.1 & 0.5 & 1.9 & 1.8 & 1.5 \\
Total & $\mathbf{1 0 0 \%}$ & $\mathbf{1 0 0 \%}$ & $\mathbf{1 0 0 \%}$ & $\mathbf{1 0 0 \%}$ & $\mathbf{1 0 0 \%}$ \\
(n) & $\mathbf{( 2 8 0 )}$ & $\mathbf{( 2 0 3 )}$ & $\mathbf{( 4 2 7 )}$ & $\mathbf{( 3 2 5 )}$ & $\mathbf{( 1 2 3 5 )}$ \\
\hline
\end{tabular}

Source: Field data, 2017

The study also examined the message framing of the $\mathrm{MCH}$-related issues published by the sampled newspapers over the study period. Table 3 shows that majority of the items analysed in the study adopted the coping frame, emphasising the effectiveness of efforts geared towards improving $\mathrm{MCH}$ care or suggesting how the various conditions can be effectively and appropriately managed to improve $\mathrm{MCH}$ outcomes. About two-thirds $(65.8 \%, \mathrm{n}=813)$ of the total 1,235 items analysed in the study adopted the coping frame. One in three adopted the alarm frame $(32.7 \%, \mathrm{n}=404)$, focusing on the severity of the $\mathrm{MCH}$ issues, people's vulnerability to its negative outcomes, and the need for enhanced effort to combat possible negative outcomes. A minute per- 
centage of less than two percent $(1.5 \%, \mathrm{n}=18)$ combined the two approaches adopting the mixed frame. All the four sampled newspapers adopted similar trends in their coverage as they all had coping faming as their leading frames of coverage, followed by alarm frame, and lastly the mixed frame.

A closer examination of the analysed stories (Table 4) however show that majority of the stories adopting coping or alarm frames were actually from planned events while spontaneous events were mostly reported using Alarm frame.

Table 4

Cross-tabulation of message frame and sources of $\mathrm{MCH}$-related items

\begin{tabular}{lcccc}
\hline \multirow{2}{*}{ Story sources } & \multicolumn{3}{c}{ Message Frame (\%) } & \\
\cline { 2 - 3 } & Alarm & Coping & Mixed & Total \\
\hline Planned event & 27.6 & 38.9 & 18.9 & 35.0 \\
Authors' analysis & 19.8 & 22.2 & 25.0 & 21.4 \\
No Source Indicated & 12.8 & 13.1 & 31.3 & 13.2 \\
Agency reports & 18.8 & 9.4 & 6.2 & 12.4 \\
Spontaneous Event & 9.9 & 3.9 & 0.0 & 5.8 \\
Interviews & 3.6 & 5.0 & 6.2 & 4.6 \\
Press Release & 1.8 & 4.7 & 6.2 & 3.8 \\
Research Findings / Reports / & 3.6 & 1.7 & 6.2 & 2.4 \\
Communique & & & & \\
Social media & 0.3 & 1.1 & 0.0 & 0.8 \\
Investigations / Tip off & 1.8 & 0.0 & 0.0 & 0.6 \\
\hline Total & $\mathbf{1 0 0 \%}$ & $\mathbf{1 0 0 \%}$ & $\mathbf{1 0 0 \%}$ & $\mathbf{1 0 0 \%}$ \\
& $\mathbf{( 3 8 4 )}$ & $\mathbf{( 7 8 5 )}$ & $\mathbf{( 1 6 )}$ & $\mathbf{( 1 1 8 5 )}$ \\
\hline
\end{tabular}

Source: Field data, 2017 


\section{DISCUSSION}

This study finds minimal use of public health frame with majority of the $\mathrm{MCH}$ related items lacking context necessary to better engage the reading public. Most focused on providing information on preventive measures and efforts at addressing $\mathrm{MCH}$ in the country as evidenced in the domination of preventives themes in the analysed items. The lack of contextual information in most of the analysed items may be attributed to the dominance of straight news reports in the analysed items which hardly provide for elaboration. For health stories to attract attention of policymakers, they must be strategically created and compellingly written to evoke the appropriate response (Thorson, 2006). Straight news reports are unlikely to allow for such elaborate coverage required for effective communication of $\mathrm{MCH}$ issues. Unfortunately, the typical newsroom routine favours the publication of straight news over detailed coverage of issues, as reporters are expected to submit regular stories from their beat irrespective of occurrence of news-worthy events (Fishman, 1980). The situation still applies in contemporary newsroom environment with greater pressure on newsmen now forced to produce more timely contents, with far limited resources. Health reporters however need to be more creative to ensure inclusion of contextual information in more health stories to evoke appropriate reaction of policy makers and the public.

The second research question examines the use of alarm and coping message frames as previously investigated in Chang's (2012) study. Finding from this study indicates dominant use of coping frames; contradicting Chang's finding of dominant use of alarm frames. Unlike their counterparts in Taiwan, Nigerian newspapers focused their coverage of $\mathrm{MCH}$-related issues on efforts being adopted to address $\mathrm{MCH}$, rather than emphasising severity of the issues. Chang notes that emphasising severity tend to heighten people's fear regarding health issues, creating a notion of helplessness among them. Nigerian newspapers thus appears more interested in portraying a positive outlook for $\mathrm{MCH}$ care.

The high adoption of coping frame by Nigerian newspapers was however more prevalent in coverage of organised events, while spontaneous occurrences were more likely to be reported with the alarm frame (Table 4). The limited focus on the severity of $\mathrm{MCH}$ in the country could therefore be attributed to journalists' reliance on organised events for many of the analysed items. The organised events reported in the analysed items were more likely to focus on efforts being made by specific groups or 
government in addressing $\mathrm{MCH}$. It appears that journalists covering the issues simply focused on the aspects event organisers focused on, hence the greater likelihood of adopting the coping frame. These findings thus support the notion that "journalistic discourse is often shaped by external forces, elites, advocates and movements" (Carragee \& Wim, 2004).

The greater adoption of coping frame in coverage of $\mathrm{MCH}$ issues may however suggest that $\mathrm{MCH}$ is being effectively managed, in the country, thus creating a false impression on the true reality of $\mathrm{MCH}$. In covering $\mathrm{MCH}$ issues in Nigeria where there is a poor disposition towards media health coverage, the combination of coping $\&$ alarm (mixed) frame may prove more appropriate as it may potentially stimulate development in the sector by drawing attention to the inherent challenges in $\mathrm{MCH}$, while emphasising efforts to address the situation for improved outcomes. Unfortunately, the mixed frame, was rarely used in the analysed items. Chang (2012) hints on the benefits of the mixed frame in coverage of health issues noting it could help people cope with health issues by alerting people to the severity of an issue and providing information on how to respond to such threats.

The relatively low adoption of public health frame and dominant use of coping frame evidenced in this study reflect the limitation of increasing reliance on coverage of organised events for news contents in Nigerian newspapers, often resulting in lack of context in coverage of issues. Reporting public health issue such as $\mathrm{MCH}$ without putting such issues in perspectives is unlikely to achieve adequate public enlightenment on reported issues, nor stimulate policy makers to take appropriate actions. Positive framing, focusing on efforts being put in place to address the issues and associated risk factors, over contextual reporting to put the issues in perspective for better understanding, could create false impression among the populace and policymakers that appropriate measures are being put in place to address the situation. However, the country's poor indices in varying aspects of $\mathrm{MCH}$ (Nigeria Health Watch, 2017; World Health Organisation, 2014) suggest otherwise, hence the need for the media to increase advocacy for improved MCH. Findings from this study thus suggest that newspapers framing of maternal and child healthcare issues in Nigerian often lack context necessary to better engage the reading public, and possibly attract required attention of policymakers. 


\section{CONCLUSION}

The relatively low adoption of public health frame and dominant use of coping frames in coverage of $\mathrm{MCH}$ issues reflects the tendency of the Nigerian media to rely on official information hand-outs (Akanni, 2015; Jimoh, 2015) which often focus on positive developments being projected by relevant promoters of such information. It is a manifestation of the unpleasant effect of media-source relations. This study suggests that health promoters influences media coverage and framing of health issues. Health promoters can therefore stimulate better framing of $\mathrm{MCH}$ issues in Nigeria through regular media engagement with news media professionals on contextualisation of reported issues, to stimulate desired growth in the sector. Nigeria Newspapers need to be proactive and independent in their coverage of $\mathrm{MCH}$ issues; developing appropriate frames of reference that can drive development of healthcare. Newspapers and other media have social responsibility to the society. There is a need for continuous publication of pressing $\mathrm{MCH}$ issues, and to communicate health strategies that could enhance $\mathrm{MCH}$ in the country. This is not just an issue that affects women and children; it has an overwhelming impact on the larger society. Hence, the media must strive for better contextualisation of $\mathrm{MCH}$ issues against all odds and despite the prevailing challenges in the industry.

The analysis of $\mathrm{MCH}$-related items published in Nigerian newspapers conducted in this study adopted the quantitative approach to frame analysis. Further studies could explore a more qualitative approach for a more reflective framing analysis of the issue. It will also be interesting to explore factors influencing adopted frames of references in newspaper coverage of health issues by adopting the sociology of news approach in interrogating health journalists on possible determinants influencing their framing of health issues. This could promote better understanding of the underlying reasons influencing similarities in framing patterns adopted by the sampled newspapers in their coverage of $\mathrm{MCH}$ issues. 


\section{REFERENCES}

Adeniran, R.A. (2018). Patterns of newspaper coverage of maternal and child healthcare issues in Nigeria, 2015-2016 (Unpublished Doctoral thesis). School of Communication, Lagos State University, Lagos Nigeria.

Ahmed, R., \& Bates B. R. (2013). Communicating health through the mass media: An overview. In R. Ahmed, \& B. R. Bates, (Eds.), Health Communication and Mass Media: An Integrated Approach to Policy and Practice (pp. 3-18). Farnham, Surrey: Gower.

Akanni, T. M. (2015). The Nigerian press coverage of oil-induced conflicts in selected Niger Delta communities. (Unpublished Doctoral thesis). Institute of Peace and Conflict Studies, University of Ibadan, Ibadan, Nigeria.

Atkin, C., \& Arkin, E. B. (1990). Issues and initiatives in communicating health information. In C. Atkin and L. Wallack (Eds.). Mass communication and public health: Complexities and conflicts (pp. 13-40). Newbury, CA: Sage.

Bello, S. M. (2015). Newspaper Coverage of Health Issues in Nigeria: The frequency of reporting malaria, HIV/AIDS and polio and the effect of seeking health information on the health behaviours of newspaper readers (Unpublished doctoral dissertation). University of Canterbury, New Zealand. Retrieved August 24, 2016 from https://ir.canterbury.ac.nz/xmlui/bitstream/handle/10092/11639/Bello\%20 Semiu\%20-\%20Final\%20PhD\%20Thesis.pdf? sequence=1\&isAllowed $=\mathrm{y}$

Cacciatore, M. A., Scheufele, D. A., \& Iyengar, S. (2016). The end of framing as we know it ... and the future of media effects. Mass Communication and Society, 19(1), 7-23. https://doi.org/10.1080/15205436.2015.1068811

Carragee, K. M. \& Wim, R. (2004). The Neglect of Power in Recent Framing Research, Journal of Communication, 54 (2), 214-233. https://doi. $\operatorname{org} / 10.1111 /$ j.1460-2466.2004.tb02625.x

Chang, C. (2012). News Coverage of Health-Related Issues and Its Impacts on Perceptions: Taiwan as an Example. Health Communication, 27, 111-123. https:// doi.org/10.1080/10410236.2011.569004

D’Angelo, P. (2002). News framing as a multiparadigmatic research program: A response to Entman. Journal of Communication, 52(4), 870-888. https://doi. org/10.1111/j.1460-2466.2002.tb02578.x 
Dare, O. (2009, July). Narrating the Nigeria Story: The Challenge for Journalism. Paper presented at a lecture in commemoration of Prof Wole Soyinka's 75th birthday organised by the Wole Soyinka Centre for Investigative Journalism (WSCIJ), Lagos. Retrieved January 9, 2016 from http://www.wscij.org/downloads/narrating_the_nigeria_story.pdf

Dorfman, L., Wallack, L., \& Woodruff, K. (2005). More Than a Message: Framing Public Health Advocacy to Change Corporate Practices. Health Education and Behavior, 32(3), 320-336. https://doi.org/10.1177/1090198105275046

Entman, R. M. (1993). Framing: Towards clarification of a fractured paradigm. Journal of Communication, 43(4), 51-58.

Entman, R. M. (2004). Projections of Power: Framing News, Public Opinion, and U.S. Foreign Policy. Chicago, IL, USA: University of Chicago Press.

Federal Ministry of Health, Nigeria (2006). National Health Promotion Policy. Abuja: Author. Retrieved July 12, 2014 from https://www.afro.who.int/publications/ national-health-promotion-policy

Fishman, M. (1980). Manufacturing the news. Texas: University of Texas Press

Gottfredsdottir, H., Magnúsdóttir, H., \& Hálfdánsdóttir, B. (2015). Home birth constructed as a safe choice in Iceland: A content analysis on Icelandic media. Sexual and Reproductive Healthcare, 6(3). 138-144. https://doi.org/10.1016/j. srhc.2015.05.004

Gruhn, R., \& Hawkins K. (2004, August). Content and framing of children's health reportage. Paper presented at the meeting of the Association for Education in Journalism and Mass Communication, Toronto, Canada.

Hawkins, K., W., \& Linvill, D. L. (2010). Public Health Framing of News Regarding Childhood Obesity in the United States. Health Communication, 25(8), 709-717. https://doi.org/10.1080/10410236.2010.521913

Jimoh, J. (2011). Commercialisation, mass media and the imperatives of health communication. In L. Oso \& U. Pate (Eds.), Mass media and society in Nigeria (pp. 77-94). Surulere, LA: Malthouse. 
Jimoh, J. P. (2015). Conflict-sensitive journalism and Nigerian print media coverage of the Jos crisis, 2010-2011 (Unpublished Doctoral thesis). Institute of Peace and Conflict Studies, University of Ibadan, Ibadan, Nigeria.

Kayode, J., \& Adeniran, R. (2012). Nigerian newspaper coverage of the Millennium Development Goals: The role of the media. Itupale Online Journal of African Studies, IV. Retrieved August 24, 2012 from http://www.cambridgetoafrica.org/ resources/Itupale_Volume_4_2012.htm\#title_1

Kayode, J., \& Thanny, N. T. (2013). The mass media and behavioural change: Lessons from family planning and health communication Campaigns in Nigeria. Retrieved January 24, 2015 from https://www.researchgate.net/publication/258218002_ Mass_Media_and_Behavioural_Change_Lesson_from_Family_Planning_and_ Health_Communication_Campaigns_in_Nigeria

Kline, K. N. (2003). Popular media and health: Images, effects, and institutions. In T. L. Thompson, A. M. Dorsey, K. I. Miller, \& R. Parrott (Eds.), Handbook of health communication (pp. 557-581). Mahwah, NJ: Lawrence Erlbaum Associates.

Kline, K. N. (2006). A decade of research on health content in the media: The focus on health challenges and sociocultural context and attendant informational and ideological problems. Journal of Health Communication: International Perspectives, 11(1), 43-59. https://doi.org/10.1080/10810730500461067

Laboli L., Caselli L., Filice A., Russi G., \& Belletti E., (2010) The unbearable lightness of health science reporting: A week examining Italian print media. PLoS ONE 5(3), e9829. https://doi.org/10.1371/journal.pone.0009829

Lebow, M, A. (1999). The pill and the press: reporting risks (Clinical commentary). Obstetrics and Gynecology, 93(3), 453-456.

Levey, N. N. (2013). The media and healthcare reform. Journal of American Medical Association, 310 (18), 1941-1942.

McQuail, D. (2005). McQuail's mass communication theory (5th ed.). London: Sage.

National Population Commission (NPC) [Nigeria] \& ICF International (2014). Nigeria Demographic and Health Survey 2013. Abuja: Author. 
Nigeria Health Watch (2017, August 16). Giving birth in Nigeria: The staggering odds facing pregnant women. Retrieved May 15, 2018 from https://nigeriahealthwatch.com/giving-birth-in-nigeria-the-staggering-odds-facing-pregnantwomen/\#Ww0qSNTRXIV

Nwabueze, C. (2005/2006). Re-appraising the vulture reporting hypothesis: A study of mass media coverage of the "Okija Shrine" crisis in Anambra State. The Nigerian Journal of Communications, 173-181.

Olukotun, A. (2017). Governance and the media in an emergent democracy: A study of the role, record and changing profile of the Nigerian media 1999-2017. An inaugural lecture of the Department of Political Science, Olabisi Onabanjo University, Ago-Iwoye.

Oso, L. (2012). Press and politics in Nigeria: On whose side? Being $47^{\text {th }}$ Edition of Lagos State University Inaugural Lecture series delivered on Tuesday, 9th October, 2012. Ojo, Lagos: Lagos State University Press.

Soola, E. O., \& Alawode, S. O. (2013). Reporting the reporter: An evaluation of health reporting among radio and television outfits in Lagos Nigeria. Journalism and Mass Communication, 3(4), 213-225.

Tankard, J. W. (2001). The empirical approach to the study of media framing. In S. D. Reese, O. H. Gandy, Jr., \& A. E. Grant (Eds.), Framing public life (pp. 95-106). Mahwah, NJ: Erlbaum.

Thorson, E. (2006). Print news and health psychology: Some observations. Journal of Health Psychology, 11(2) 175-182. https://doi.org/10.1177/1359105306061178

Wallack, L., \& Dorfman, L. (1996). Media advocacy: A strategy for advancing policy and promoting health. Health Education Quarterly, 23(3), 293-317. https://doi. org/10.1177/109019819602300303

Wang, Z., \& Gantz, W. (2010) Health content in local television news: A current appraisal. Health Communication, 25(3), 230-237. https://doi. org/10.1080/10410231003698903

World Health Organisation (2014). Nigeria: Health profile. Retrieved May 30, 2015 from http://www.afro.who.int/en/nigeria/country-health-profile.html 